\title{
Response to Adefovir Depends on Mutation Patterns in Precore Region, Basal Core Promoter and Reverse Transcriptase, and On-Treatment Responses in Lamivudine-Resistant Chronic Hepatitis B Patients
}

\author{
Byung-Cheol Song $^{a}$ Xiu Ji Cui ${ }^{a}$ Jung Woo Shin ${ }^{b}$ Neung Hwa Park ${ }^{b}$ \\ Yoo-Kyung Cho ${ }^{a}$ Hyun Joo Song ${ }^{a}$ Soyoung Hyun ${ }^{a}$ Seung Uk Jeong ${ }^{a}$ \\ Eun Kwang Choi ${ }^{a}$ Heung Up Kim ${ }^{a}$

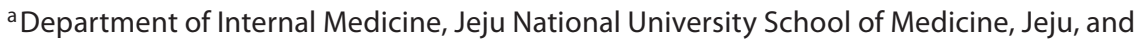 \\ ${ }^{b}$ Department of Internal Medicine, University of Ulsan College of Medicine, Ulsan University Hospital, Ulsan, Korea
}

\section{Key Words}

Chronic hepatitis B - Lamivudine resistance $\cdot$ Adefovir •

Precore region $\cdot$ Basal core promoter

\begin{abstract}
Objective: In vitro studies showed that mutations in the basal core promoter $(\mathrm{BCP})$ or precore $(\mathrm{PC})$ region restore the replication inefficiency of the lamivudine-resistant mutant. The aim of this study was to clarify the effect of molecular characteristics on the antiviral response to adefovir in patients with lamivudine-resistant chronic hepatitis B (CHB). Methods: Sixty-six lamivudine-resistant patients who were treated with adefovir monotherapy were studied. Sequences of $\mathrm{BCP}, \mathrm{PC}$ region and reverse transcriptase were determined before adefovir therapy. In patients with virologic breakthrough, reverse transcriptase sequencing was performed. Results: The cumulative probabilities of virologic response were $23.3,46,52.7$ and $59.5 \%$ at years 1, 2, 3 and 4, respectively. PC mutation, the absence of compensatory mutations (rtL80I/V or rtV173L), and a decrease in serum hepatitis B virus (HBV) DNA by 3 log or greater at 6 months were independent predictors of virologic response. The cumulative
\end{abstract}

probabilities of virologic breakthrough were $0,12.9,30.7$ and $44.5 \%$ at years 1, 2, 3 and 4, respectively. BCP mutation and a less than 3 log decrease in serum HBV DNA at 6 months were 2 independent risk factors for virologic breakthrough. Conclusion: Response to adefovir depends on mutation patterns in the $B C P, P C$ region and reverse transcriptase, and ontreatment decreases in serum HBV DNA in lamivudine-resistant $\mathrm{CHB}$ patients.

Copyright $\odot 2010$ S. Karger AG, Basel

\section{Introduction}

With the introduction of oral nucleoside/nucleotide analogs (NA), NA treatment has prevented the progression of chronic hepatitis $\mathrm{B}(\mathrm{CHB})$ and the development of hepatocellular carcinoma (HCC) $[1,2]$. In spite of this advancement, resistance to NA is still a major challenge for antiviral therapy.

Lamivudine is one of the widely used NA. However, long-term use of lamivudine increases the risk of drug resistance [3, 4]. Lamivudine resistance harbors the rtM204V/I mutation. In addition, compensatory muta-

\section{KARGER}

Fax +41613061234 E-Mail karger@karger.ch www.karger.com
(C) 2010 S. Karger AG, Base

$0300-5526 / 10 / 0534-0203 \$ 26.00 / 0$

Accessible online at:

www.karger.com/int
Byung-Cheol Song, MD

Department of Internal Medicine

Jeju National University School of Medicine

1753-3 Ara-dong, Jeju 690-716 (Republic of Korea)

Tel. +82 64717 1528, Fax +82 64717 1131, E-Mail drsong@ jejunu.ac.kr 
tions of $\mathrm{rtL180M}$, rtL80I/V and $\mathrm{rtV} 173 \mathrm{~L}$ are also present [5-10].

Adefovir has been reported to be effective in suppressing hepatitis B virus (HBV) DNA in NA-naïve and lamivudine-resistant patients [11]. It has been reported that resistance to adefovir is high in lamivudine-resistant patients in Korea [12, 13], suggesting that some geographical and virologic factors may affect antiviral responses to adefovir therapy.

The HBV genotype might have clinical relevance in terms of natural course and antiviral response, especially in those treated with interferon [14, 15], and most studies have reported that NA did not affect the antiviral response in terms of HBeAg loss and resistance $[16,17]$. Most CHB patients in Korea are infected with genotype C $[18,19]$, which frequently harbors mutation A1762T/ G1764A in the basal core promoter (BCP) [19-21]. In vitro studies showed that mutations in the precore (PC; $\mathrm{G} 1896 \mathrm{~A}$ ) or in the BCP region of HBV restore the replication inefficiency of lamivudine-resistant mutants [22, 23]. In addition, compensatory mutations of $\mathrm{rtL80I/V}$ are usually accompanied by rtM204I [24, 25]. In contrast, $\mathrm{rtV} 173 \mathrm{~L}$ is usually accompanied by an rtM204V mutation [5]. These compensatory mutations restore the replication competency of lamivudine-resistant viruses similar to the level of wild-type HBV $[5,6]$. These observations suggest that molecular characteristics of the mutant virus may affect the antiviral response in lamivudine-resistant patients.

Therefore, the aim of this study was to clarify the effect of molecular characteristics of mutant viruses on the antiviral response to adefovir in lamivudine-resistant $\mathrm{CHB}$ patients.

\section{Patients and Methods}

In this retrospective cohort study, data were collected from 66 of 70 consecutive, compensated, lamivudine-resistant $\mathrm{CHB}$ patients treated with sequential adefovir monotherapy between October 2003 and August 2006.

Patients were included in the study if they were 18 years or older and had compensated liver disease (Child-Pugh class A). Patients were excluded if they had HCC, a liver transplantation, received immunotherapy or chemotherapy, or if they were coinfected with human immunodeficiency virus, or hepatitis C or D viruses. Patients with hepatic decompensation (hepatic encephalopathy, recent variceal bleeding, uncontrolled ascites, serum bilirubin of $>2.0 \mathrm{mg} / \mathrm{dl}$ and serum albumin of $<3.0 \mathrm{~g} / \mathrm{dl}$ ) and a serum creatinine concentration of $>1.4 \mathrm{mg} / \mathrm{dl}$ were also excluded. Four patients were excluded from this analysis because serum was not available before the beginning of the adefovir therapy.
HBsAg, anti-HBs, HBeAg and anti-HBe were tested by thirdgeneration microparticle enzyme immunoassays using commercial kits (Abbott, North Chicago, Ill., USA). Serum HBV DNA levels were measured using Cobas Amplicor HBV Monitor kits with a detection limit of $60 \mathrm{IU} / \mathrm{ml}$ (Roche Molecular Systems, Pleasanton, Calif., USA). Before August 2005, HBV DNA was measured using a Digene Hybrid Capture assay (Digene Corp., Gaithersburg, Md., USA). Therefore, serum HBV DNA levels in these periods were retested by Cobas Amplicor HBV Monitor, using stored serum at the time of analysis. The HBV genotype was determined by the $S$ gene sequence, and sequences of PC, BCP and reverse transcriptase were determined before the beginning of the adefovir therapy in all patients, as previously reported [19].

Virologic response was defined as an undetectable serum HBV DNA $(<60 \mathrm{IU} / \mathrm{ml})$ during treatment, and biochemical response was defined as a decrease in serum alanine transaminase (ALT) levels within the normal range. Virologic breakthrough was defined as an increase in serum HBV DNA by $>1 \log _{10}$ above the nadir while on treatment [26].

During the study period, the Korean national insurance system only covered the use of adefovir monotherapy as a rescue therapy in lamivudine-resistant CHB patients, based on the study by Peters et al. [11]. Therefore, all patients were treated with sequential adefovir monotherapy before December 2007. After that, most patients were recommended to receive a combination therapy of adefovir and lamivudine as most guidelines for $\mathrm{CHB}$ recommended add-on combination therapy $[26,27]$. Therefore, data collection ended in November 2007. The patients were followed up at 1- to 3-month intervals.

The serum samples were collected by written informed consent from the patients, and the study protocol was approved by the ethics committees of our institutions.

Statistical Analysis

Differences between the categorical variables were analyzed by the $\chi^{2}$ test. For the continuous variables, the Student $t$ test was used. The cumulative probability of virologic response and the virologic breakthrough rate were calculated by the Kaplan-Meier method, and the difference was determined by the log-rank test. In multivariate analysis, Cox's proportional hazard model was used. $\mathrm{p}<0.05$ (two-tailed) was considered to be statistically significant.

\section{Results}

The baseline characteristics of the 66 study patients are shown in table 1 . All patients were infected with genotype C, especially subgenotype C2. rtM204I, rtM204V, rtM204I/V mutations and the wild type were found in 36 patients (54.5\%), 25 patients (37.9\%), 4 patients (6.1\%) and 1 patient (1.5\%), respectively, prior to adefovir therapy. rtL80I/V mutation was observed in 27 patients. This mutation was observed in 24 patients with the rtM204I mutant, and in 3 patients with the rtM204I/V mixed-type mutant. rtV173L mutation was observed in 9 patients. This mutant was observed in 6 patients with the rtM204V, 


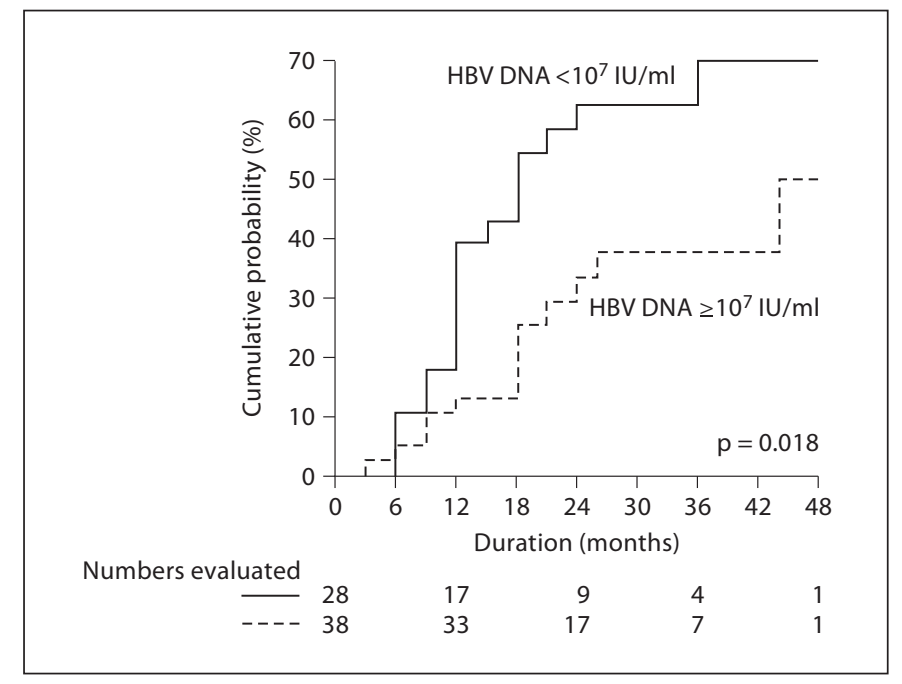

Fig. 1. Cumulative rate of virologic response depending on $\mathrm{HBV}$ DNA levels. It was higher in patients with serum levels of HBV DNA of $<10^{7} \mathrm{IU} / \mathrm{ml}$ than in those with serum levels of HBV DNA of $\geq 10^{7} \mathrm{IU} / \mathrm{ml}(40,62.4,70$ and $70 \%$ vs. $13.2,33.2,37.7$ and $50 \%$ at years 1, 2, 3 and 4 , respectively; $\mathrm{p}=0.018$ ).

in 2 patients with the $\mathrm{rtM} 204 \mathrm{I} / \mathrm{V}$, and in 1 patient with the rtM204I mutant.

During sequential adefovir monotherapy, the cumulative probabilities of virologic response were 23.3, 42.1, 52.7 and $59.5 \%$ at years $1,2,3$ and 4 , respectively. A biochemical response was achieved in $62.7,88,88$ and $88 \%$ of the patients at years 1,2, 3 and 4, respectively. Among $55 \mathrm{HBeAg}$-positive $\mathrm{CHB}$ patients, $\mathrm{HBeAg}$ loss was achieved by $7.2,15,20.7$ and $20.7 \%$ at years $1,2,3$ and 4 , respectively. The cumulative rate of virologic response was higher in patients with serum levels of HBV DNA of $<10^{7} \mathrm{IU} / \mathrm{ml}$ (mean value of the study) than in those with serum levels of HBV DNA of $\geq 10^{7} \mathrm{IU} / \mathrm{ml}(40,62.4,70$ and $70 \%$ vs. 13.2, 33.2, 37.7 and $50 \%$; $=0.018$ ) (fig. 1). It was also higher in patients with PC mutation than in those without $(50,72.2,81.5$ and $81.5 \%$ vs. $7.5,29.7,36.1$ and $46.8 \%$ at years $1,2,3$ and $4 ; \mathrm{p}=0.001$ ) (fig. 2). Patients without compensatory mutations of rtL80I/V or rtV173L had a higher probability of virologic response compared to those with these mutations ( $\mathrm{p}=0.046$ ) (fig. 3). There was no difference in virologic response rate according to age, sex, serum ALT level or the pattern of rtM204/ rtL180M mutation.

On treatment, the virologic response rate was higher in patients with a 3 log or greater decrease in HBV DNA at 6 months than in patients without $(40.6,76,82$ and $82 \%$ vs. $3,19.1,27.2$ and $41.7 \%$ at years $1,2,3$ and 4 , respec-

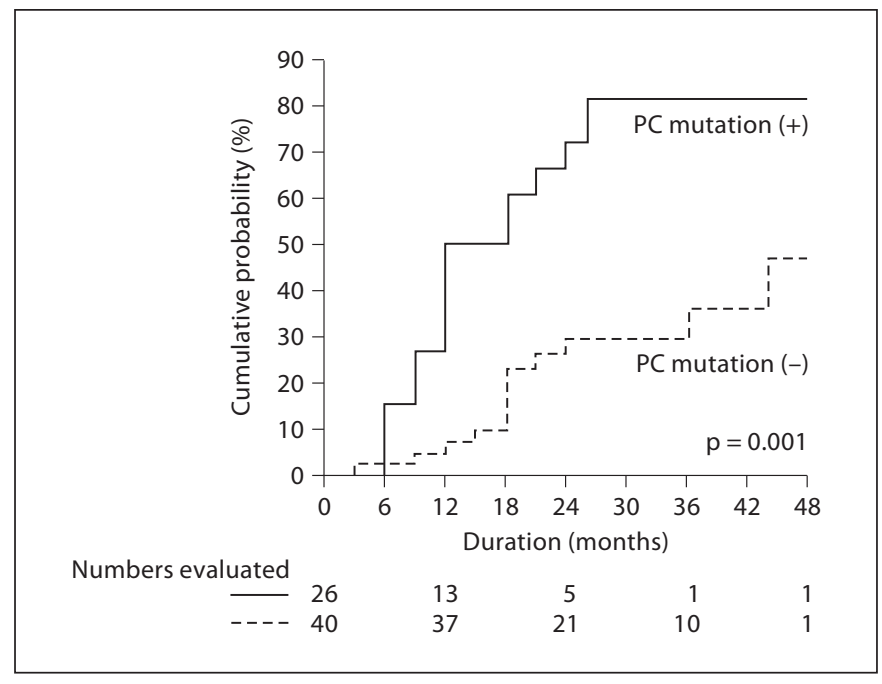

Fig. 2. Cumulative rate of virologic response depending on $P C$ mutation. It was higher in patients with PC mutation than in those without $(50,72.2,81.5$ and $81.5 \%$ vs. $7.5,29.7,36.1$ and $46.8 \%$ at years $1,2,3$ and 4 , respectively; $\mathrm{p}=0.001$ ).
Table 1. Baseline characteristics of study patients

\begin{tabular}{lc}
\hline Age, years & $43.0 \pm 12.1$ \\
Male/female gender, $\mathrm{n}$ & $54 / 12$ \\
HBV genotypes (C2), n & $66(100 \%)$ \\
Serum ALT, IU/ml & $177(49-738)$ \\
HBeAg positive, $\mathrm{n}$ & $59(89.4 \%)$ \\
HBV DNA (log), IU/ml & $6.96 \pm 1.1(4.4-10.4)$ \\
Primary rtM204 mutations, $\mathrm{n}$ & \\
$\quad$ rtM204I & $36(54.5 \%)$ \\
$\quad$ rtM204V & $25(37.9 \%)$ \\
$\quad$ rtM204I/V & $4(6.1 \%)$ \\
rtM204M & $1(1.5 \%)$ \\
Compensatory mutations, $n$ & \\
$\quad$ rtL180M & $46(69.7 \%)$ \\
$\quad$ rtL80I/V & $27(40.9 \%)$ \\
$\quad$ rtV173L & $9(13.6 \%)$ \\
BCP mutation, $n$ & $52(78.8 \%)$ \\
PC mutation, $n$ & $26(39.4 \%)$ \\
Duration of ADV therapy, months & $31.8 \pm 10.3$ \\
\end{tabular}

Values are means \pm SD unless stated otherwise. $\mathrm{ADV}=$ Adefovir dipivoxil.

tively; $\mathrm{p}<0.001$ ) (fig. 4). In multivariate analysis, PC mutation, the absence of compensatory mutations (rtL80I/V or $\mathrm{rtV} 173 \mathrm{~L}$ ), and a $3 \log$ or greater decrease in HBV DNA levels at 6 months were independent predictive factors for virologic response (table 2). 


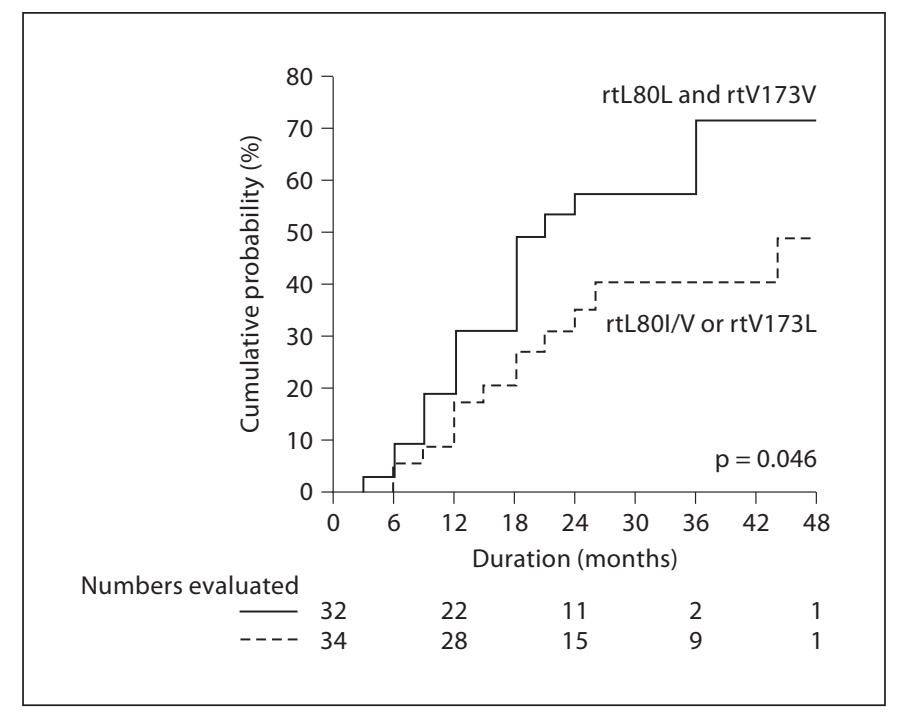

Fig. 3. Cumulative rate of virologic response depending on compensatory mutation. Patients without compensatory mutations (rtL80L and $\mathrm{rtV} 173 \mathrm{~V}$ ) had a higher probability of virologic response compared to those with these mutations (rtL80I/V or rtV173L; 31.2, 57.2, 71.4 and $71.4 \%$ vs. $17.6,35.4,40$ and $48.5 \%$ at years 1, 2, 3 and 4 , respectively; $\mathrm{p}=0.046$ ).

Table 2. Independent predictive factors for virologic response during adefovir monotherapy in lamivudine-resistant $\mathrm{CHB}$ patients

\begin{tabular}{lll}
\hline & Odds ratio & $\mathrm{p}$ \\
\hline $\begin{array}{l}\text { PC mutation } \\
\quad \text { No }\end{array}$ & 1 & 0.004 \\
$\quad$ Yes & $3.5(1.8-8.1)$ & \\
Compensatory mutation (rt80/rt173) & & 0.025 \\
$\quad$ No & 1 & \\
$\quad$ Yes & $0.4(0.2-0.9)$ & \\
$\begin{array}{l}\text { Decrease in HBV DNA at } 6 \text { months } \\
\quad<3 \text { log IU/ml }\end{array}$ & 1 & \\
$\quad \geq 3$ log IU/ml & $4.9(2.1-11.6)$ & \\
HBV DNA before adefovir therapy & & 0.001 \\
$\quad<10^{7} \mathrm{IU} / \mathrm{ml}$ & 1 & \\
$\quad \geq 10^{7} \mathrm{IU} / \mathrm{ml}$ & $0.8(0.4-2.1)$ & \\
\hline
\end{tabular}

Values in parentheses denote 95\% CI.

Virologic breakthrough occurred in 19 of the 66 patients. Seventeen of the 19 patients with virologic breakthrough harbored known adefovir-resistant mutants $(\mathrm{rtA} 181 \mathrm{~T} / \mathrm{V}, \mathrm{n}=10 ; \mathrm{rtN236T}, \mathrm{n}=5 ; \mathrm{rtA181T} / \mathrm{V}$ and rtN236T, $n=2$ ), while 2 patients did not harbor any

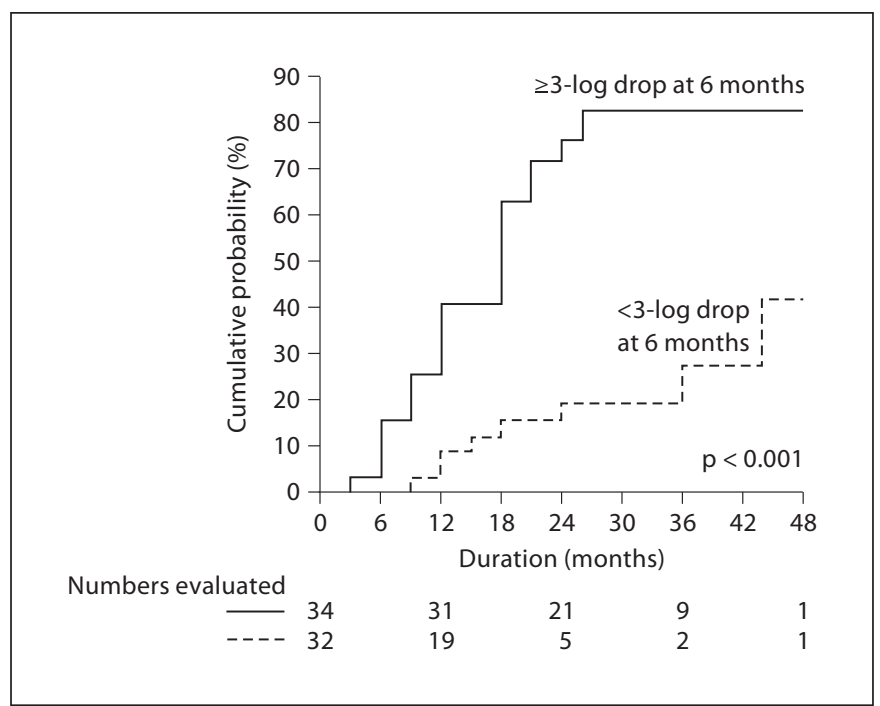

Fig. 4. Cumulative rate of virologic response depending on decrease in serum levels of HBV DNA at 6 months. The virologic response rate was higher in patients with a $3 \log$ or greater decrease in HBV DNA at 6 months than in patients without (40.6, 76,82 and $82 \%$ vs. $3,19.1,27.2$ and $41.7 \%$ at years $1,2,3$ and 4 , respectively; $\mathrm{p}<0.001)$.

known adefovir-resistant mutant. In a patient without a known adefovir-resistant mutant, a genotypic switch from genotype $\mathrm{C}$ to genotype $\mathrm{A}$ after virologic breakthrough was observed.

The cumulative probabilities of virologic breakthrough were $0,12.9,30.7$ and $44.5 \%$ at years $1,2,3$ and 4 , respectively. As a result, persistent virologic response, defined as an undetectable HBV until the final follow-up, was achieved only in 27 of the 66 patients (40.1\%).

The virologic breakthrough rate was higher in patients with the BCP mutation than in those without $(0,16,36.3$ and $55 \%$ vs. $0,0,10$ and $10 \%$ at years $1,2,3$ and $4 ; \mathrm{p}=$ 0.045) (fig. 5). It was also higher in patients without a 3 log or greater decrease in serum HBV DNA at 6 months than in those with such a decrease $(0,15.4,43$ and $64.5 \%$ vs. $0,10.1,14$ and $14 \%$ at years $1,2,3$ and 4 , respectively; $\mathrm{p}=0.018$ ) (fig. 6). It was also higher in patients with detectable serum HBV DNA at 1 year than in patients with undetectable serum HBV DNA at 1 year $(0,17.3,39.6$ and $54.55 \%$ vs. $0,0,6.2$ and $6.2 \%$ at years $1,2,3$ and 4 , respectively; $\mathrm{p}=0.02$ ). There was no difference in virologic breakthrough rate according to age, gender, $\mathrm{HBeAg}$, serum ALT, PC mutation, serum HBV DNA level or mutation pattern in reverse transcriptase, including $\mathrm{rtL} 80 \mathrm{I} / \mathrm{V}$, rtV173L, rtL180M and rtM204. In multivariate analysis, 


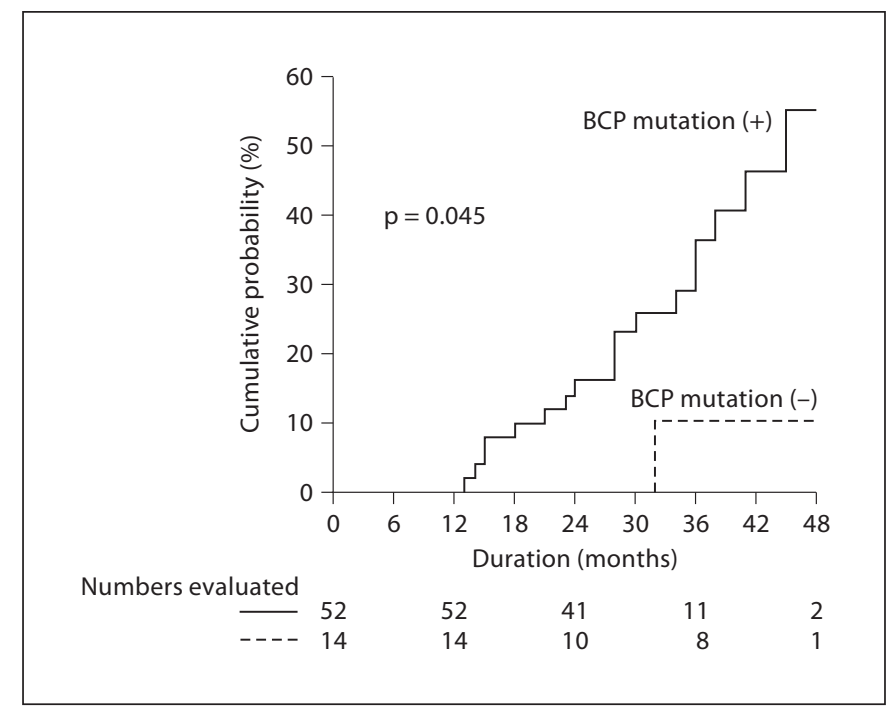

Fig. 5. Cumulative rate of virologic breakthrough depending on BCP mutation. It was higher in patients with BCP mutation than in those without $(0,16,36.3$ and $55 \%$ vs. $0,0,10$ and $10 \%$ at years $1,2,3$ and 4 , respectively; $\mathrm{p}=0.045)$.

the presence of a BCP mutation and a decrease in serum HBV DNA levels at 6 months were 2 independent risk factors for virologic breakthrough (table 3).

\section{Discussion}

The goal of antiviral therapy for $\mathrm{CHB}$ is to improve the quality of life and survival by preventing the progression of the disease to liver cirrhosis, HCC or death. This goal can be achieved if HBV replication can be suppressed in a sustained manner [28], which could decrease the risk of progression to liver cirrhosis and the development of HCC [1].

In this study, the cumulative probabilities of virologic response and virologic breakthrough rate at year 4 were 59.5 and $44.5 \%$, respectively. An on-treatment persistent virologic response, defined as an undetectable $\mathrm{HBV}$ until the final follow-up, was achieved in only $40.1 \%$ of the patients. The virologic response at 1 year, using the same definition $(<60 \mathrm{IU} / \mathrm{ml})$, was similar to that in previous reports of $22-33.8 \%[12,24,29]$.

In this study, independent predictive factors for virologic response were the presence of a PC mutation and the absence of any additional compensatory mutations of

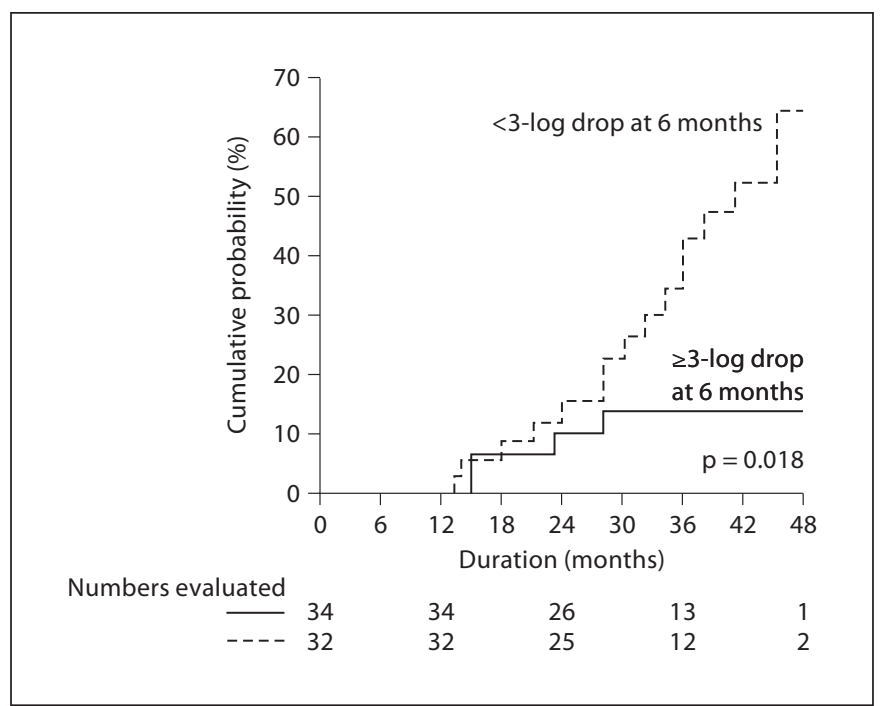

Fig. 6. Cumulative rate of virologic breakthrough depending on HBV DNA response at 6 months. It was higher in patients without a $3 \log$ or greater decrease in serum HBV DNA at 6 months than in those with such a decrease $(0,15.4,43$ and $64.5 \%$ vs. $0,10.1,14$ and $14 \%$ at years $1,2,3$ and 4 , respectively; $\mathrm{p}=0.018$ ).

Table 3. Independent risk factors for virologic breakthrough during adefovir monotherapy in lamivudine-resistant $\mathrm{CHB}$ patients

\begin{tabular}{lll}
\hline & Odds ratio & $\mathrm{p}$ \\
\hline $\begin{array}{l}\text { BCP mutation } \\
\quad \text { No }\end{array}$ & 1 & 0.05 \\
$\quad$ Yes & $7.2(1.0-54.6)$ & \\
$\begin{array}{l}\text { Decrease in HBV DNA at 6 months } \\
\quad<3 \text { log IU/ml }\end{array}$ & 1 & 0.01 \\
$\quad \geq 3$ log IU/ml & $0.3(0.13-0.8)$ & \\
HBV DNA before adefovir therapy & & 0.5 \\
$\quad<10^{7} \mathrm{IU} / \mathrm{ml}$ & 1 & \\
$\quad \geq 10^{7} \mathrm{IU} / \mathrm{ml}$ & $1.4(0.5-3.7)$ & \\
\hline
\end{tabular}

Values in parentheses denote 95\% CI.

rtL80I/V or rtV173L, in addition to a decrease in serum HBV DNA by 3 log or greater at 6 months. Previous studies suggest that the pretreatment level of serum HBV DNA is a predictive factor for virologic response [30-32]. The pretreatment level of HBV DNA was a predictive factor for virologic response in univariate analysis in this study, but showed marginal significance in multivariate 
analysis. This result might be due to our small sample size. An on-treatment decrease in serum HBV DNA level was a good indicator for virologic response, similar to that in NA-naïve patients [33], even in CHB patients with lamivudine resistance. Therefore, on-treatment monitoring of serum HBV DNA is very important in the prediction of virologic response.

In vitro studies show that $\mathrm{rtL} 80 \mathrm{I} / \mathrm{V}, \mathrm{rtV} 173 \mathrm{~L}, \mathrm{PC}$ and BCP mutations restore the replication inefficiency of a lamivudine-resistant mutant $[5,6,22,23]$. On this aspect, we hypothesized that these mutations might influence the antiviral response. In this study, rtL80I/V mutation was associated with rtM204I or mixed-type mutation (rtM204I/V). rtV173L mutation was associated with rtM204V or mixed-type mutation, which confirmed previous observations $[5,24,25]$. These results support those of the previous in vitro study that rtL80I or rtV173L enhances the replication efficiency of rtM204 mutant viruses. Therefore, a high replication efficiency of these mutants with rtL80I/V or rtV173L might influence the virologic response to adefovir.

PC mutation was a good indicator for virologic response, whereas BCP mutation did not influence virologic response. Previously, it has been reported that a reversion from PC mutation to the wild type has occasionally been observed in patients treated with lamivudine, suggesting an increased sensitivity to lamivudine in the PC mutant in vivo [34, 35]. However, this phenomenon has not yet been reported for adefovir therapy.

In this study, the cumulative rates of virologic breakthrough were $0,12.9,30.7$ and $44.5 \%$ at years $1,2,3$ and 4 , respectively. Resistances to adefovir were $0,3,11,18$ and $29 \%$ at years $1,2,3,4$ and 5, respectively, in NAnaïve $\mathrm{HBeAg}$-negative $\mathrm{CHB}$ patients [36]. Therefore, this study supports the previous report on the result that adefovir resistance increases in patients with lamivudine resistance compared with NA-naïve patients [12]. In this study, most cases of virologic breakthrough were associated with the development of adefovir resistance. Interestingly, a genotypic switch from genotype $\mathrm{C}$ to genotype A after virologic breakthrough was observed in 1 patient. Recently, Jardi et al. [37] reported that a selection of genotype A forms mixed strains during antiviral therapy. Therefore, these results might suggest that sensitivity to antiviral therapy might differ between genotypes.

Resistance to adefovir was reported to be $0-18 \%$ at 1 year in patients with lamivudine resistance $[11-13,30,32$, 38-40]. However, the virologic breakthrough rate at 1 year was relatively low in this study. This result might be attributed to the methodological difference. Previous studies tested resistance profiles at 1 year regardless of virologic breakthrough. However, we only performed mutational analyses if the patients showed virologic breakthrough. Yeon et al. [13] reported that genotypic resistance to adefovir in lamivudine-resistant patients occurred in $6.4 \%$ of the cases at 1 year, and the virologic breakthrough rate was $0 \%$ at 1 year. In addition, Fung et al. [41] and Liu et al. [29] did not find any genotypic resistance to adefovir during 48 weeks of adefovir monotherapy in lamivudine-resistant CHB patients. Recently, Idilman et al. [30] reported that the cumulative probabilities of virologic breakthrough rate were 1.2, 15.1 and $37.3 \%$ at years 1, 2 and 3, respectively, which was very similar to the results of our study.

Several factors are associated with the development of antiviral resistance, but the key ones, based on our current understanding, are the potency of the antiviral agents, the replication fitness of HBV and the genetic barrier of the antiviral agent, as well as host factors [26, 42].

In previous studies, patients with a high baseline viral load were more likely to develop adefovir resistance [38, 39]; however, some studies did not show the same results $[13,31,41]$. Our study also denied the correlation between pretreatment serum HBV DNA level and virologic breakthrough. We showed that the levels of HBV DNA at 6 months and 1 year - these on-treatment responses usually reflect the drug potency in each individual - were associated with virologic breakthrough. This observation was in line with some previous studies [30, 36, 38, 43], suggesting that the on-treatment $\mathrm{HBV}$ response might be important to predict adefovir resistance.

Interestingly, the $\mathrm{BCP}$ mutation increased the probability of adefovir resistance regardless of the HBV DNA level and on-treatment response. In vitro studies showed that the presence of a BCP mutation increased viral replication above the wild-type baseline level in the wild type [44-47] and even in the lamivudine-resistant mutant viruses [23]. Therefore, the increasing replication fitness of the BCP mutation in lamivudine-resistant viruses might persist and eventually induce virologic breakthrough during adefovir treatment.

However, we observed different virologic responses and breakthroughs according to mutation patterns (rtL80I/V, rtV173L, PC and BCP mutations), even though these mutants have been reported to increase replication fitness in vitro $[5,6,22,23]$. This finding suggests that other factors than replication fitness, such as immune systems, or host cellular enzymes necessary for converting prodrugs to their active compounds or for phosphor- 
ylating antiviral agents to their triphosphates $[42,48]$, influence virologic outcomes.

The major limitation of this study is that sequential adefovir monotherapy is not recommended any more for lamivudine-resistant $\mathrm{CHB}$ patients according to many guidelines $[26,28]$. Therefore, our data can be applied only to sequential adefovir monotherapy patients.

In conclusion, the response to adefovir therapy depends on mutation patterns in the $\mathrm{PC}$ region, $\mathrm{BCP}$ and reverse transcriptase, and on the on-treatment decrease in serum HBV DNA in lamivudine-resistant CHB patients.

\section{Acknowledgment}

This study was supported by the 2007 Korean Association for the Study of the Liver Research Fund.

\section{References}

1 Liaw YF, Sung JJ, Chow WC, Farrell G, Lee CZ, Yuen H, Tanwandee T, Tao QM, Shue K, Keene ON, Dixon JS, Gray DF, Sabbat J: Lamivudine for patients with chronic hepatitis $\mathrm{B}$ and advanced liver disease. $\mathrm{N}$ Engl J Med 2004;351:1521-1531.

-2 Yuen MF, Seto WK, Chow DH, Tsui K, Wong DK, Ngai VW, Wong BC, Fung J, Yuen JC, Lai CL: Long-term lamivudine therapy reduces the risk of long-term complications of chronic hepatitis B infection even in patients without advanced disease. Antivir Ther 2007;12:1295-1303.

-3 Lai CL, Dienstag J, Schiff E, Leung NW, Atkins $M$, Hunt C, Brown N, Woessner M, Boehme R, Condreay L: Prevalence and clinical correlates of YMDD variants during lamivudine therapy for patients with chronic hepatitis B. Clin Infect Dis 2003;36:687-696.

-4 Chang TT, Lai CL, Chien RN, Guan R, Lim SG, Lee CM, Ng KY, Nicholls GJ, Dent JC, Leung NW: Four years of lamivudine treatment in Chinese patients with chronic hepatitis B. J Gastroenterol Hepatol 2004; 19 : 1276-1282.

-5 Delaney WE 4th, Yang H, Westland CE, Das K, Arnold E, Gibbs CS, Miller MD, Xiong S: The hepatitis B virus polymerase mutation $\mathrm{rtV} 173 \mathrm{~L}$ is selected during lamivudine therapy and enhances viral replication in vitro. J Virol 2003;77:11833-11841.

6 Warner N, Locarnini S, Kuiper M, Bartholomeusz A, Ayres A, Yuen L, Shaw T: The L80I substitution in the hepatitis $B$ virus polymerase is associated with lamivudine resistance and enhanced viral replication in vitro. Antimicrob Agents Chemother 2007; 51:2285-2292.

7 Villet S, Pichoud C, Villeneuve JP, Trépo C, Zoulim F: Selection of a multiple drug-resistant hepatitis B virus strain in a liver-transplanted patient. Gastroenterology 2006;131: 1253-1261.

$\checkmark 8$ Melegari M, Scaglioni PP, Wands JR: Hepatitis B virus mutants associated with 3TC and famciclovir administration are replication defective. Hepatology 1998;27:628-633.
9 Ono-Nita SK, Kato N, Shiratori Y, Masaki T, Lan KH, Carrilho FJ, Omata M: YMDD motif in hepatitis B virus DNA polymerase influences on replication and lamivudine resistance: a study by in vitro full-length viral DNA transfection. Hepatology 1999;29:939945.

10 Ono SK, Kato N, Shiratori Y, Kato J, Goto T, Schinazi RF, Carrilho FJ, Omata M: The polymerase L528M mutation cooperates with nucleotide binding-site mutations, increasing hepatitis $\mathrm{B}$ virus replication and drug resistance. J Clin Invest 2001;107:449455.

11 Peters MG, Hann Hw H, Martin P, Heathcote EJ, Buggisch P, Rubin R, Bourlière $M$, Kowdley K, Trépo C, Gray Df D, Sullivan M, Kleber K, Ebrahimi R, Xiong S, Brosgart CL: Adefovir dipivoxil alone or in combination with lamivudine in patients with lamivudine-resistant chronic hepatitis B. Gastroenterology 2004;126:91-101.

12 Lee YS, Suh DJ, Lim YS, Jung SW, Kim KM, Lee HC, Chung YH, Lee YS, Yoo W, Kim SO: Increased risk of adefovir resistance in patients with lamivudine-resistant chronic hepatitis B after 48 weeks of adefovir dipivoxil monotherapy. Hepatology 2006;43:1385-1391.

13 Yeon JE, Yoo W, Hong SP, Chang YJ, Yu SK, Kim JH, Seo YS, Chung HJ, Moon MS, Kim SO, Byun KS, Lee CH: Resistance to adefovir dipivoxil in lamivudine-resistant chronic hepatitis B patients treated with adefovir dipivoxil. Gut 2006;55:1488-1495.

14 Flink HJ, Hansen BE, Heathcote EJ, Feinman SV, Simsek H, Karayalcin S, Mach T, Leemans WF, de Man RA, Verhey E, Schalm SW, Janssen HL: Successful treatment with peginterferon alfa-2b of HBeAg-positive HBV nonresponders to standard interferon or lamivudine. Am J Gastroenterol 2006;101:2523-2529.

-15 Kao JH, Wu NH, Chen PJ, Lai MY, Chen DS: Hepatitis B genotypes and the response to interferon therapy. J Hepatol 2000;33:9981002 .
16 Yuen MF, Tanaka Y, Lai CL: Hepatitis B genotypes in chronic hepatitis $\mathrm{B}$ and lamivudine therapy. Intervirology 2003;46:373-376.

17 Yuen MF, Wong DK, Sablon E, Yuan HJ, Sum SM, Hui CK, Chan AO, Wang BC, Lai CL: Hepatitis B virus genotypes $B$ and $C$ do not affect the antiviral response to lamivudine. Antivir Ther 2003;8:531-534.

18 Song BC, Cui XJ, Kim H: Hepatitis B virus genotypes in Korea: an endemic area of hepatitis B virus infection. Intervirology 2005; 48:133-137.

19 Song BC, Cui XJ, Kim HU, Cho YK: Sequential accumulation of the basal core promoter and the precore mutations in the progression of hepatitis B virus-related chronic liver disease. Intervirology 2006;49:266-273.

20 Kao JH, Chen PJ, Lai MY, Chen DS: Hepatitis $B$ genotypes correlate with clinical outcomes in patients with chronic hepatitis B. Gastroenterology 2000;118:554-559.

-21 Orito E, Mizokami M, Sakugawa H, Michitaka $\mathrm{K}$, Ishikawa $\mathrm{K}$, Ichida $\mathrm{T}$, Okanoue $\mathrm{T}$, Yotsuyanagi $\mathrm{H}$, Iino S: A case-control study for clinical and molecular biological differences between hepatitis B viruses of genotypes B and C. Japan HBV Genotype Research Group. Hepatology 2001;33:218-223.

22 Chen RY, Edwards R, Shaw T, Colledge D, Delaney WE 4th, Isom H, Bowden S, Desmond P, Locarnini SA: Effect of the G1896A precore mutation on drug sensitivity and replication yield of lamivudine-resistant HBV in vitro. Hepatology 2003;37:27-35.

$\checkmark 23$ Tacke F, Gehrke C, Luedde T, Heim A, Manns MP, Trautwein C: Basal core promoter and precore mutations in the hepatitis $B$ virus genome enhance replication efficacy of lamivudine-resistant mutants. J Virol 2004; 78:8524-8535.

24 Lee YS, Chung YH, Kim JA, Kim SE, Shin JW, Kim KM, Lim YS, Park NH, Lee HC, Lee YS, Suh DJ: Hepatitis B virus with the $\mathrm{rtL} 80 \mathrm{~V} / \mathrm{I}$ mutation is associated with a poor response to adefovir dipivoxil therapy. Liver Int 2009;29:552-556. 
-25 Ogata N, Fujii K, Takigawa S, Nomoto M, Ichida T, Asakura $\mathrm{H}$ : Novel patterns of amino acid mutations in the hepatitis $B$ virus polymerase in association with resistance to lamivudine therapy in Japanese patients with chronic hepatitis B. J Med Virol 1999; 59:270-276

26 Lok AS, McMahon BJ: Chronic hepatitis B. Hepatology 2007;45:507-539.

27 Lee KS, Kim DJ: Management of chronic hepatitis B: KASL guidelines. Kor J Hepatol 2007;13:447-488.

28 European Association for the Study of the Liver: EASL Clinical Practice Guidelines: management of chronic hepatitis B. J Hepatol 2009;50:227-242.

-29 Liu CJ, Kao JH, Chen PJ, Chen TC, Lin FY, Lai MY, Chen DS: Overlap lamivudine treatment in patients with chronic hepatitis B receiving adefovir for lamivudine-resistant viral mutants. J Viral Hepat 2006;13:387-395.

-30 Idilman R, Kaymakoglu S, Oguz Onder F, Ahishali E, Bektas M, Cinar K, Pinarbasi B, Karayalcin S, Badur S, Cakaloglu Y, Mithat Bozdayi A, Bozkaya H, Okten A, Yurdaydin $\mathrm{C}$ : A short course of add-on adefovir dipivoxil treatment in lamivudine-resistant chronic hepatitis B patients. J Viral Hepat 2009;16:279-285.

-31 Buti M, Elefsiniotis I, Jardi R, Vargas V, Rodriguez-Frias F, Schapper M, Bonovas S, Esteban R: Viral genotype and baseline load predict the response to adefovir treatment in lamivudine-resistant chronic hepatitis B patients. J Hepatol 2007;47:366-372.

-32 Lampertico P, Vigano M, Manenti E, Iavarone $\mathrm{M}$, Lunghi $\mathrm{G}$, Colombo $\mathrm{M}$ : Adefovir rapidly suppresses hepatitis $\mathrm{B}$ in $\mathrm{HBeAg-}$ negative patients developing genotypic resistance to lamivudine. Hepatology 2005;42: 1414-1419.

-33 Lai CL, Leung N, Teo EK, Tong M, Wong F, Hann HW, Han S, Poynard T, Myers M, Chao G, Lloyd D, Brown NA: A 1-year trial of telbivudine, lamivudine, and the combination in patients with hepatitis $\mathrm{B}$ e antigenpositive chronic hepatitis B. Gastroenterology $2005 ; 129: 528-536$
34 Cho SW, Hahm KB, Kim JH: Reversion from precore/core promoter mutants to wild-type hepatitis B virus during the course of lamivudine therapy. Hepatology 2000;32:11631169.

35 Lok AS, Hussain M, Cursano C, Margotti M, Gramenzi A, Grazi GL, Jovine E, Benardi M, Andreone P: Evolution of hepatitis B virus polymerase gene mutations in hepatitis $\mathrm{B}$ antigen-negative patients receiving lamivudine therapy. Hepatology 2000;32:11451153.

36 Hadziyannis SJ, Tassopoulos NC, Heathcote EJ, Chang TT, Kitis G, Rizzetto M, Marcellin P, Lim SG, Goodman Z, Ma J, Brosgart CL, Borroto-Esoda K, Arterburn S, Chuck SL: Long-term therapy with adefovir dipivoxil for $\mathrm{HBeAg-negative} \mathrm{chronic} \mathrm{hepatitis} \mathrm{B} \mathrm{for}$ up to 5 years. Gastroenterology 2006;131: 1743-1751.

37 Jardi R, Rodriguez-Frias F, Schaper M, Giggi E, Tabernero D, Homs M, Esteban R, Buti M Analysis of hepatitis $B$ genotype changes in chronic hepatitis B infection: influence of antiviral therapy. J Hepatol 2008;49:695701.

38 Chen $\mathrm{CH}$, Wang JH, Lee CM, Hung CH, Hu TH, Wang JC, Lu SN, Changchien CS: Virological response and incidence of adefovir resistance in lamivudine-resistant patients treated with adefovir dipivoxil. Antivir Ther 2006;11:771-778.

39 Rapti I, Dimou E, Mitsoula P, Hadziyannis SJ: Adding-on versus switching-to adefovir therapy in lamivudine-resistant HBeAgnegative chronic hepatitis $B$. Hepatology 2007;45:307-313.

40 Manolakopoulos S, Bethanis S, Koutsounas S, Goulis J, Vlachogiannakos J, Christias E, Saveriadis A, Pavlidis C, Triantos C, Christidou A, Papatheodoridis G, Karamanolis D, Tzourmakliotis D: Long-term therapy with adefovir dipivoxil in hepatitis B e antigennegative patients developing resistance to lamivudine. Aliment Pharmacol Ther 2008; 27:266-273.
41 Fung SK, Chae HB, Fontana RJ, Conjeevaram $\mathrm{H}$, Marrero J, Oberhelman $\mathrm{K}$, Hussain M, Lok AS: Virologic response and resistance to adefovir in patients with chronic hepatitis B. J Hepatol 2006;44:283-290.

42 Ghany MG, Doo EC: Antiviral resistance and hepatitis B therapy. Hepatology 2009; 49:S174-S184.

43 Fung SK, Andreone P, Han SH, Rajender Reddy K, Regev A, Keeffe EB, Hussain M, Cursaro C, Richtmyer P, Marrero JA, Lok AS: Adefovir-resistant hepatitis B can be associated with viral rebound and hepatic decompensation. J Hepatol 2005;43:937-943.

$>44$ Baumert TF, Rogers SA, Hasegawa K, Liang TJ: Two core promoter mutations identified in a hepatitis B virus strain associated with fulminant hepatitis result in enhanced viral replication. J Clin Invest 1996;98:2268-2276.

-45 Liang TJ, Hasegawa K, Munoz SJ, Shapiro CN, Yoffe B, McMahon BJ, Feng C, Bei H, Alter MJ, Dienstag JL: Hepatitis B virus precore mutation and fulminant hepatitis in the United States: a polymerase chain reactionbased assay for the detection of specific mutation. J Clin Invest 1994;93:550-555.

46 Liang TJ, Hasegawa K, Rimon N, Wands JR, Ben-Porath E: A hepatitis B virus mutant associated with an epidemic of fulminant hepatitis. N Engl J Med 1991;324:1705-1709.

-47 Omata M, Ehata T, Yokosuka O, Hosoda K, Ohto $\mathrm{M}$ : Mutations in the precore region of hepatitis B virus DNA in patients with fulminant and severe hepatitis. N Engl J Med 1991;324:1699-1704.

-48 Lok AS, Zoulim F, Locarnini S, Bartholomeusz A, Ghany MG, Pawlotsky JM, Liaw YF, Mizokami M, Kuiken C: Antiviral drug-resistant HBV: standardization of nomenclature and assays and recommendations for management. Hepatology 2007;46: 254-265. 